\title{
The Demographic Factor Impact on the Economics of the Arctic Region
}

\author{
Irina Gennadyevna Gerasimova ${ }^{1} \mathbb{D}$, Irina Sergeevna Oblova ${ }^{1, *}$ and Ekaterina Ilinichna Golovina ${ }^{2}$ \\ 1 Department of Foreign Languages, Faculty of Humanities and Sciences, Saint Petersburg Mining University, \\ 199106 St. Petersburg, Russia; Gerasimova_IG@pers.spmi.ru \\ 2 Department of Economics, Organization and Management, Faculty of Economics, Saint Petersburg Mining \\ University, 199106 St. Petersburg, Russia; Golovina_EI@pers.spmi.ru \\ * Correspondence: Oblova_IS@pers.spmi.ru
}

check for updates

Citation: Gerasimova, I.G.; Oblova, I.S.; Golovina, E.I. The Demographic Factor Impact on the Economics of the Arctic Region. Resources 2021, 10, 117. https://doi.org/10.3390/ resources10110117

Academic Editors: Elena Rada and Eva Pongrácz

Received: 30 September 2021 Accepted: 10 November 2021 Published: 16 November 2021

Publisher's Note: MDPI stays neutral with regard to jurisdictional claims in published maps and institutional affiliations.

Copyright: (c) 2021 by the authors. Licensee MDPI, Basel, Switzerland. This article is an open access article distributed under the terms and conditions of the Creative Commons Attribution (CC BY) license (https:/ / creativecommons.org/licenses/by/ $4.0 /)$.

\begin{abstract}
Decline of the international price of some minerals, such as coal, has changed the living standards of the Arctic population leading to its considerable out-migration because of the drop in profitability not only in mining, but also in related industries. Being essential for the sustainable economic development, the highly qualified specialists are currently a crucial issue in the Arctic. This research employs demographic and economic indicators to address the gap in the study of demographic challenges for the Arctic administrative-territorial entities. Special attention is paid to the comparative analysis of the population dynamic in the Russian and global Arctic regions. As part of this study, the impact of the demographic factor on the economic indicators of the region was assessed on the basis of GRP data calculation. Special attention is paid to the analysis of the major trends in the Arctic labour market. Based on the results of the assessment, an increase in GRP was determined with the simultaneous decrease in the Arctic population. The current demographic situation in the Arctic regions in the context of gender factors was reviewed. It should be noted that the article contains exceptions and the causes of the phenomena described. The results of the research may contribute to better understanding of regional variation and trends in socio-economic development of the Arctic as well as the stabilisation of the Arctic population.
\end{abstract}

Keywords: arctic; economics; mineral resource; population; mining; economic indicators; gross regional product (GRP); female

\section{Introduction}

The Arctic region has gained its growing geopolitical and global economic significance due to the wealth of mineral resources, the improvement of shipping between the countries of Europe, Asia, and North America as well as increasing global concern about the environment in the face of changing climate. Given the fact that the current ecological, social, and economic challenges in the Arctic require both top-rank engineers to realise the promise of the Arctic and maximisation of economic benefits at the regional level. Ensuring of the sustainable economic and social advancement of the Arctic is impossible without effective economic management of the region. The assessment of the interdependency of some economic indicators of the region and the demographic factor is still a fragmented field. The present study intends to contribute to filling this gap by presenting a study of economic performance of Arctic administrative-territorial entities on a global and regional scale depending on their local population. The population outflow from the Russian Arctic has been a major trend since the collapse of the USSR. The relevance of the study is provided by the current boost in exploration, construction activities, and therefore an urgent need for population stabilisation in the Russian Arctic. As a matter of fact, the Russian Arctic population accounts for only $1.6 \%$. At the same time, $10 \%$ of Russian GDP is ensured by this region. However, GRP per capita in the Russian Arctic region is much lower than in any other Arctic region in the world. 
The Arctic is exploited as a vast reservoir of natural resources serving the world market, and this large-scale resource extraction largely structures the rest of its economic activity. The Arctic currently supplies natural gas, oil, and ores to the global economy and has reserves to keep on with this for quite some time. The Arctic indigenous population combines traditional life and production with participation in the market economy. The share of manufacturing is still low in the Arctic regions. Furthermore, the Arctic areas have shown capacity to develop service industries based on shipbuilding and ship repairing centres located in Arkhangelsk, Murmansk regions and in Alaska, agriculture (e.g., sheep farming in the Faroe Islands), power engineering (e.g., nuclear energy in Russia and geothermal energy in Iceland), and tourism. The development of the Arctic territory, in particular for the regions of the Far North needs a contemporary approach to address the issue of increasing and stabilising inhabitants. This challenge remains especially for the single-industry towns dependent on mining. The decline in the world market prices for some minerals, such as coal, has led to significant changes in the living standards of the population not only in single-industry towns themselves, but also in economic areas as a whole, which in turn resulted in the marked out-migration owing to the drop in profitability both in mining industry, and in related sectors.

State strategic interests in the development of the Arctic zone are specified in a number of programmes and reports (e.g., "Strategy of the socio-economic development of the Yamalo-Nenets Autonomous District until 2030," “Interdisciplinary Arctic Research. Areas of cooperation of Saint-Petersburg and the Arctic regions of the Russian Federation" etc.). However, shrinking of skilled labour force imposes some pressure on their implementation. Foremost, the most qualified personnel being in demand in some other more prosperous regions are leaving the Arctic.

The correlation between the demographic and economic indicators has been discussed in numerous scientific papers [1,2]. This type of correlation for the Arctic region has been the focus of research conducted by a number of scientists [3,4]. In the book "Comprehensive studies of territorial development" V.N. Lazhentsev suggested that abundance of mineral deposits proves to be one of the distinguishing characteristics of the northern territories [5]. The primary sector in the Arctic consists primarily of the large-scale extraction of nonrenewable resources, the value and volume of which is immense. The North of Russia produces $93 \%$ of natural gas, $75 \%$ of oil, $100 \%$ of diamonds, cobalt, platinum, and apatite concentrate, $90 \%$ of copper and nickel, $65 \%$ of gold, $15 \%$ of coal as well as contributes around the half of the total forestry and fishing products [6].

Gender bias has persisted in the Arctic since the earliest polar expeditions, which gender and colonial roots laid the basis for polar science (Bloom, 1993; Glasberg, 2012) [7,8]. Women could not undertake scientific research and highlight their scientific contributions in the polar regions in the 1990s (Chipman, 1986; Carey, Jackson, Antonello, \& Rushing, 2016; Seag, 2017) [9-11]. Gendered barriers are divided into formal, caused by social, political, and economic factors (Rosner, 2009; Lahiri-Dutt, 2019, Marsh, et al. (2011) [12-14] and informal ones including physical barriers; low paid work and harassment (Bell \& Koenig, 2017) [15]. Recent scholarly works, events, and webinars (Starkweather, S., Derry, K., \& Crain, R. 2018; Association of Polar Early Career Scientists [APECS], 2019; Smieszek \& Prior, 2019) [16-18] have shown a light on the struggles faced by women in their careers in the Arctic.

Nowadays women in the Arctic have elevated their visibility and empowered their voices across the world. Female names are becoming more and more common among workers in the complex technical fields of research, where there were barely any women scientists a few decades ago. Event of the Arctic Congress 2018 Women of the Arctic: Bridging Policy, Research and Lived Experience hosted by the University of Helsinki on 6 and 7 September 2018 raised questions about the merits and relevance of the women in the Arctic [19] and drew on the experiences of women politicians, entrepreneurs, and civil society leaders to analyse how to bring up the next generation of female leaders. 
The British non-profit organisation "Women in Mining UK" has contributed to the assistance of businesses and governments in attracting, retaining, and promoting female professionals to various industrial areas. In 2020, the Russian mining enterprises Polymetal and Nornickel, together with the consulting company Deloitte in the CIS, launched a project "Women in Mining Russia" to promote female leadership in mining and invest in human capital as well as gender diversification in the traditionally very conservative and maledominated sectors. The Association seeks to provide a wide range of informational services, exchange expertise and adopt the positive experience of "Women in Mining UK". The key functions of the partners of the Russian Association, viz. leading engineering universities such as the Saint Petersburg Mining University, National Research Technological University "MISIS", and Siberian Federal University are to create expert collaboration and guide career development programmes for recruiting interested female youth [20]. The project aims at increasing the prestige of engineering specialties among the female talented human resources and promote international cooperation (the "Mining by country and continent" series), industrial and training tourism [21]. The Assessment conducted by the USA National Petroleum Council (2019) underscored the importance of the mining industry to oversee and verify Arctic OCS drilling regulations as well as to bring appropriate technology and operating practices to bear. The assessment affirms the shared responsibility of industry and government to secure and maintain women's participation in the mining industry [22].

In the context of tremendous diversity of ideas and approaches concerning women of the Arctic, scholars and researchers around the world have added some important insights into understanding gender issues in the Arctic. Gjørv (2016) presented her view of the concept "gender" and focused on closely interconnected intersectional analysis of security based on multiple identities of gender, race, ethnicity, class, age, and other social categories [23]. The joint international research intended to complement study on gender in North America and the Nordic countries encouraged wider use of feminist approaches in geography and social sciences and discussed gender in relation to identity and intersectionality under colonial and post-colonial conditions [24]. Seag et al. addressed overlapping, interconnected barriers to equality and progress in polar research faced by female polar researchers like gender identity, sexuality, and a lack of opportunities and recognition [25].

Notwithstanding a steadily growing number of Arctic venues, initiatives regarding Arctic women gender imbalance determined by the Russian and foreign scientists remain valid today. Furthermore, although there is a strong tradition of studying demography as part of economics there is merely a very short study that particularly refers to the influence of the demographic factor on the economic indicators of the region as well as proportion of women employed in mining and differences of Russian and foreign legislative base of the women's involvement in mining in the Arctic.

The goal of the paper is to identify the influence of the demographic factor on the economy of the Russian Arctic. To achieve this goal, the following tasks are set:

1. Characteristics of the demographic situation in the Russian Arctic in the context of sustainable development.

2. Review of the current demographic situation in the Arctic regions in the context of gender factors.

3. Analysis of the main trends in the Arctic labour market.

4. Analysis of the economic indicator of GRP for comparing the administrative territories of the Arctic.

5. Development of recommendations for the efficient use of the Arctic potential.

\section{Materials and Methods}

As the Arctic is increasingly recognised as being central to human and planetary survival it needs a comprehensive overview of its territory, population, and resources. Typically, overall economic performance of the region is characterised by gross regional 
product (GRP) data being an indicator of the output of the region estimated at current market prices of goods and services in its calculation (nominal gross regional product) as well as at constant prices (real gross regional product). GRP is the gross value added of goods and services developed by residents of the region defined as the difference between output and intermediate consumption. GRP is very close in economic content to gross domestic product (GDP). However, GDP at the federal level is not identical to GRP at the regional level. The sum of gross regional products in Russia does not include value added for non-market collective services (defence, public administration, etc.) provided by the state institutions to society as a whole and to this extent it is unequal to GDP. Vast statistics and documents of subarctic countries, in particular, Canada, USA, Norway, etc., have been analysed. The study employs the direct method of demographic research to analyse gender composition of employees in the Arctic. A gender indicator employed to identify the characteristics of the population was calculated as the number of women permanently residing in the region per 1000 men permanently residing in the same area at the certain time. A gender indicator measures gender-related changes over time and refers to quantitative indicators based on gender statistical data providing separate measures for men and women on employment in mining. Measurements of gender equality might address changes in the relations between men and women, the outcomes of a particular policy, programme, or activity for women and men, or changes in their status.

\subsection{Areas Belonging to the Arctic Region}

The focus of the first stage of the research reported in this article was identifying the Arctic areas. It is assumed that they are governed by the norms of the national legislation of subarctic countries. The status of certain areas of the Arctic region is in international dispute because of the absence of the evident legal resolution to the competing interests of the Arctic nations claiming rights to overlapping territory. For example, the Arctic Council does not consider Labrador and Nunavik, a province of Quebec, as parts of the Arctic (Table 1).

Table 1. Arctic areas [26].

\begin{tabular}{|c|c|c|}
\hline Arctic Administrative Areas & $\begin{array}{l}\text { Recommendation of } \\
\text { the Arctic Council }\end{array}$ & $\begin{array}{l}\text { On the Report on Human } \\
\text { Development in the Arctic }\end{array}$ \\
\hline \multicolumn{3}{|l|}{ Murmansk region, Nenets } \\
\hline $\begin{array}{l}\text { Autonomous Area, the } \\
\text { Yamalo-Nenets Autonomous Okrug, } \\
\text { the Chukotka Autonomous Okrug }\end{array}$ & + & + \\
\hline The Republic of Karelia, Arkhangelsk & & \\
\hline $\begin{array}{l}\text { Region (7 urban and } \\
\text { municipal districts })\end{array}$ & + & 0 \\
\hline $\begin{array}{l}\text { The Komi Republic, the Republic of } \\
\text { Sakha (Yakutia) }\end{array}$ & + & - \\
\hline $\begin{array}{l}\text { The Khanty-Mansiysk Autonomous } \\
\text { Region, the Magadan Province }\end{array}$ & + & 0 \\
\hline $\begin{array}{c}\text { Yukon, North-West Territories } \\
\text { of Canada }\end{array}$ & + & + \\
\hline Nunavik (Quebec), Labrador & 0 & + \\
\hline Faroe Islands, Greenland & + & + \\
\hline Alaska & + & + \\
\hline $\begin{array}{l}\text { Nordland, Troms, Finnmark, } \\
\text { Spitsbergen, Jan Mayen Island }\end{array}$ & + & + \\
\hline Lapland & + & + \\
\hline Northern Ostrobothnia, Kainuu & + & 0 \\
\hline Norbotten & + & + \\
\hline County of Vasterbotten & + & 0 \\
\hline Iceland & + & + \\
\hline
\end{tabular}


As it can be seen, there is no consensus on the international approaches to defining the Arctic territorial boundaries. The vast diversity in statistics development among countries in the Arctic reflects the amount of challenges facing the region.

\subsection{Mineral Resources in the Arctic}

Being rich in mineral resources, the Arctic is at the crossroads of the geopolitical interests of eight countries currently owning it in territorial terms. This region contains $13 \%$ of the global oil reserves and $30 \%$ of natural gas, respectively (Table 2 ).

Table 2. Characteristics of the Arctic [27].

\begin{tabular}{|c|c|}
\hline Country & Mineral Resources \\
\hline Russia & $\begin{array}{c}\text { apatite, coal, cobalt, copper, gold, gypsum, iron ore, potelot, } \\
\text { nickel, palladium, platinum, silver, gems, rare-earth metals, tin, } \\
\text { titanium, zinc, diamonds, tin, antimony, peat }\end{array}$ \\
\hline Canada & diamonds, gold, gypsum, iron ore, lead, uranium, zinc \\
\hline Denmark & - \\
\hline the USA & Zinc, lead \\
\hline Norway & iron ore, copper, zinc, lead, nickel, titanium, potelot, silver \\
\hline Finland & $\begin{array}{c}\text { vanadium, chromium, apatite, cobalt, peat, iron ore, copper, zinc, } \\
\text { nickel, non-metallic mineral resources }\end{array}$ \\
\hline Sweden & $\begin{array}{c}\text { iron ore, copper, titanium, iron pyrites, zinc, uranium, silver, coal, } \\
\text { oil, natural gas }\end{array}$ \\
\hline \multirow[t]{2}{*}{ Iceland } & - \\
\hline & al cost of the deposits-USD 1.5-2 trillion \\
\hline
\end{tabular}

As, beyond existing and prospective petroleum resources, deposits in the Arctic of other mineral resources are substantial by any standards, large mining enterprises view exploration of the Arctic hydrocarbon resources as attractive commercial opportunities.

\subsection{Current Labour Market Outlook}

Currently, the economic development of the Arctic directly impacts the designated sectors of the economy forming the basis for gross regional product for the Arctic zone. Key among them are mining, oil and gas industry, fisheries and agriculture, electric power industry, transport infrastructure, civil and military shipbuilding, industrial and civil construction. With the global economy's growing demand for the Arctic natural resources, mining companies dictate their interest in the labour market. For example, the following corporations based in Murmansk region: JSC "Apatit", the world's largest enterprise (part of JSC "Phosagro", Moscow, Russia) engaged in the extraction of high-quality mineral raw materials for manufacture of phosphate fertilisers, "Kovdor mining and processing plant" (part of Russia's largest mineral fertilizer producer "EuroChem", Moscow, Russia), mining apatite and iron ore and "Olkon" (Murmansk, Russia), the most northern iron ore complex in Russia the largest non-freezing port of Russia located in the Murmansk region determine demanded occupations there. Considering the lists of the most sought-after professions for each Arctic region separately, one can distinguish similar needs of skilled and blue-collar personnel in mining associated with the predominance of "iconic" sectors of the economy (Table 3).

The main characteristics of the population of the Arctic include the high degree of urbanisation with a low population density (0.1-0.2 people per $\left.1 \mathrm{~m}^{2}\right)$. Comparing economic location and population density, it should be noted that $0.5 \%$ of the most populated Arctic territories are characterised by the greatest concentration of economy. 
Table 3. Mining in the Arctic [28-30].

\begin{tabular}{|c|c|c|c|}
\hline Country & $\begin{array}{c}\text { Population } \\
\text { Density per } 1 \text { km }^{2}\end{array}$ & $\begin{array}{l}\text { Mining Output, } \\
\text { US Dollar per } 1 \mathrm{~km}^{2}\end{array}$ & $\begin{array}{l}\text { Occupations in the } \\
\text { Mining Industry }\end{array}$ \\
\hline Asian part of Russia & 0.44 & 1642 & \\
\hline European part of Russia & 2.67 & 795 & Mine worker; \\
\hline Finland & 3.95 & 11,201 & mining engineer; \\
\hline Sweden & 3.35 & 20,022 & shaft man; surveyor; \\
\hline Norway & 4.3 & 2026 & hoist man; ore \\
\hline Iceland & 3.24 & 0 & enrichment \\
\hline Denmark (Greenland) & 0.03 & 0 & specialist; driller; \\
\hline Canada & 0.03 & 776 & geologist; IT \\
\hline the USA & 0.43 & 1974 & specialist, etc. \\
\hline
\end{tabular}

The sectoral structure of the economy has been noted above as one of the main factors both affecting the employment of women and forming the demand for specialties traditionally referred to as "male" or "female." In order to understand whether the economy of the northern regions of Russia is really characterised by resource exploitation limiting the possibility of female employment, it is necessary to research the needs of employers in those types of economic activities providing the greatest chances for women to be employed in the form of the provision of services such as wholesaling and retailing, housing, followed by education and health and social work [31-33].

\subsection{Demographics and Implications for the Economy}

Currently, most regions of the Russian North show drastic differences in the vacancies of so-called "male" economic activities [34-36]. However, the proportion of "female" vacancies does not exceed $25 \%$ in the mine-rush areas such the Yamalo-Nenets and the Chukotka Autonomous Okrugs, as well as the Republic of Sakha, whereas in the European regions of the North it averages $37 \%$. This gender gap can be explained by the long history of the development of the north of the European part of Russia, the gradual depletion of the natural resources, and the increase in the role in their economy of the secondary and tertiary sectors.

Of the 20 Arctic cities with at least 40,000 inhabitants in 2017, 12 cities are located in Russia, Western Europe amounts to 7 cities, and 1 city is situated in the United States. Out of the 9 cities, 6 cities with a population of 100,000 belong to the Russian Federation. The largest Arctic cities are Whitehorse $(25,085$ inhabitants) and Yellowknife $(19,569)$ in Canada, Nuuk $(17,796)$ and Tórshavn $(13,130)$ in Denmark. Within dynamics of populations, all foreign Arctic cities have been found to have trends in population growth, out of 12 Russian cities only 3 such as Novy Urengoy, Noyabrsk, and Severomorsk followed this tendency. Vorkuta, Monchegorsk, Murmansk, and Apatity suffered from the largest losses in the population (Table 4).

Fauser and Smirnov previously carried out estimates of GRP for the Arctic regions [26]. To assess GRP, the following sequence was followed:

1. For each Arctic coastal state, gross domestic product (GDP) was determined by World Bank data. Greenland and the Faroe Islands were taken into account as states.

2. For the states partially included in the Arctic, GDP decreased in proportion to the value of GRP of the Arctic territories in the total GRP of the state. It should be highlighted that GRP decreased in proportion to the specific rate of the population living in the Arctic. 
Table 4. The largest cities of the Arctic [37].

\begin{tabular}{|c|c|c|c|c|}
\hline \multirow{2}{*}{ City/Country } & \multicolumn{2}{|c|}{ Population, Inhabitants } & \multicolumn{2}{|c|}{$\begin{array}{l}\text { Population Growth/Decline } \\
\text { 1989-2017 }\end{array}$} \\
\hline & 1989 & 2017 & $\begin{array}{l}\text { Number of } \\
\text { Inhabitants }\end{array}$ & $\%$ \\
\hline Arkhangelsk (Russia) & 416,812 & 351,488 & $-65,324$ & -15.7 \\
\hline Anchorage (USA) & 226,338 & 298,192 & 71,854 & 31.7 \\
\hline Murmansk (Russia) & 472,274 & 298,096 & $-174,178$ & -36.9 \\
\hline Oulu Finland & 121,810 & 198,358 & 76,548 & 62.8 \\
\hline Severodvinsk (Russia) & 253,864 & 183,996 & $-69,868$ & -27.5 \\
\hline Norilsk (Russia) & 179,757 & 178,018 & -1739 & -1.0 \\
\hline Reykjavik Iceland & 95,811 & 123,246 & 27,435 & 28.6 \\
\hline Novy Urengoy (Russia) & 93,235 & 113,254 & 20,019 & 21.5 \\
\hline Noyabrsk (Russia) & 85,880 & 106,879 & 20,999 & 24.5 \\
\hline Umea, Sweden & 60,305 & 87,238 & 26,933 & 44.7 \\
\hline Tromse, Norway & 50,548 & 64,448 & 13,900 & 27.5 \\
\hline Vorkuta (Russia) & 115,329 & 58,133 & $-57,196$ & -49.6 \\
\hline Apatity (Russia) & 88,066 & 56,356 & $-31,710$ & -36.0 \\
\hline Rovaniemi, Finland & 32,941 & 52,481 & 19,540 & 59.3 \\
\hline Severomorsk (Russia) & 63,495 & 51,209 & $-12,286$ & -19.3 \\
\hline Salekhard (Russia) & 32,334 & 48,507 & 16,173 & 50.0 \\
\hline Lulea, Sweden & 42,727 & 48,268 & 5541 & 13.0 \\
\hline Nadym (Russia) & 52,586 & 44,660 & -7926 & -15.1 \\
\hline Monchegorsk (Russia) & 68,652 & 42,581 & $-26,071$ & -38.0 \\
\hline Bodo, Norway & 30,339 & 40,705 & 10,366 & 34.2 \\
\hline
\end{tabular}

The Formula (1) employed to calculate GRP

$$
G R P_{\text {ATEarc }}=G D P_{\text {country }} \cdot \frac{G R P_{\text {ATE }}}{G R P_{\text {country sum }}} \cdot \frac{\text { Population }_{\text {ATEarc }}}{\text { Population }_{\text {ATE total }}}
$$

$G R P_{A T E a r c}$-GRP of the Arctic administrative-territorial entities (ATE), USD.; GDP country -GDP of the country comprising administrative-territorial entities; $G R P_{A T E}-$ GRP of ATE valued in national currency; GRP country sum - the sum of GRP of all ATE of the country; Population $_{\text {ATEarc }}$ - the number of ATE inhabitants living in the Arctic; Population ATEtotal $_{\text {- }}$ the total population of ATE. Using this formula, GRP was calculated for all Arctic administrativeterritorial entities (Table 5).

Table 5. GRP of the administrative-territorial entities of the Global Arctic, 2016 [38,39].

\begin{tabular}{ccc}
\hline Administrative-Territorial Entities & GRP, mln. USD & GRP Per Capita, USD \\
\hline Global Arctic-total & 232,534 & 42,808 \\
\hline Russian Arctic & 68,311 & 28,279 \\
\hline Murmansk region & 7890 & 10,414 \\
\hline The Republic of Karelia & 303 & 6898 \\
\hline Arkhangelsk region & 9791 & 15,046 \\
\hline
\end{tabular}


Table 5. Cont.

\begin{tabular}{|c|c|c|}
\hline Administrative-Territorial Entities & GRP, mln. USD & GRP Per Capita, USD \\
\hline Nenets Autonomous Area & 4734 & 107,743 \\
\hline The Komi Republic & 2031 & 25,365 \\
\hline The Yamalo-Nenets Autonomous Okrug & 36,387 & 67,880 \\
\hline Krasnoyarsk Territory & 511 & 24,255 \\
\hline The Republic of Sakha (Yakutia) & 438 & 16,715 \\
\hline The Chukotka Autonomous Okrug & 1226 & 24,599 \\
\hline Alaska (the USA) & 50,712 & 68,389 \\
\hline Canada & 9101 & 56,487 \\
\hline Denmark & 4756 & 44,989 \\
\hline Greenland & 2248 & 40,250 \\
\hline Faroe Islands & 2508 & 50,297 \\
\hline Iceland & 20,047 & 59,251 \\
\hline Norway & 31,520 & 64,693 \\
\hline Nordland & 15,591 & 64,195 \\
\hline Troms & 10,812 & 65,279 \\
\hline Finnmark & 4917 & 64,565 \\
\hline Spitsbergen & 201 & 77,647 \\
\hline Jan Mayen Island & 0 & 0 \\
\hline Sweden & 23,896 & 46,270 \\
\hline Norbotten & 12,240 & 48,849 \\
\hline County of Vasterbotten & 11,656 & 43,841 \\
\hline Finland & 24,191 & 36,319 \\
\hline Lapland & 7141 & 39,665 \\
\hline Northern Ostrobothnia & 14,642 & 35,599 \\
\hline Kainuu & 2407 & 32,219 \\
\hline For reference: Global GDP & $75,847,769$ & 10,046 \\
\hline
\end{tabular}

The diversity of the sectoral structure of gross value added, calculated using the Shannon index and GRP per capita of the Russian Arctic entities (-0.828) creates a linear correlation. The results showed that the less diversified the economy of the Arctic territory is, as well as the greater the share of mining that is there (from 3.4\% in the Arkhangelsk region to $67.5 \%$ in the Nenets Autonomous Okrug), the more product it produces per resident. In those Arctic regions of the Russian Federation where the mineral sector contributes less than $15 \%$ of value added, per capita GRP is close to the world average.

The low efficiency of the Arctic is partly due to the irrational distribution of its population. In a number of the Arctic territories, the rapid migration outflow led to the redundancy of some infrastructure in the 1990-2000s. Its maintenance with a high degree of wear and tear is costly.

The Yamal-Nenets Autonomous Okrug [40] can be considered in more detail. Currently the Yamal-Nenets Autonomous Okrug involved in construction contributes 17\% of GRP, transport and communication industries together provide $7 \%$ of the GRP whereas oil and gas refinery production covers more than $95 \%$. Manufacturing industries have slowed markedly contributing to the region's economy very insignificantly, about $2 \%$. Despite the small population, the data on the economic activity of the region are significantly higher 
than the socio-economic indicators of Russia. The GRP per resident is almost 8 times higher than the average national level.

\subsection{Legislative Base concerning Gender Employment in Mining}

In spite of continual improvement of modern occupational safety and health management systems at the enterprises of the sector of mineral resources, working underground remains harmful and dangerous. Mining involves working underground with explosive substances in shifts, in conditions of high humidity, dusty air, insufficient illumination. Miners suffer from occupational diseases as vibration disease, pneumoconiosis (silicosis), mixed forms of diseases of the neuromuscular system, tumours of the respiratory system, diseases of the musculoskeletal system (rheumatism, arthritis) [41-43].

In Alaska, advocating the fundamental gender justice principles the Civil Rights Act addresses women under represented occupational areas and covers the key antidiscrimination actions or affirmative measures taken by the US Government. Its Section VII requires no person on the ground of gender be excluded from recruitment, promotion, and training as well as be denied the benefits of, or be subjected to, discrimination under any personnel policies or activities receiving Federal financial assistance.

Furthermore, Executive Order 11,246 establishes requirements for non-discriminatory practices in hiring and promotion on the part of the employers within federal contracts or subcontracts in the United States [44]. According to the Executive Order, federal contractors and federally assisted construction contractors and subcontractors (having 50 or more employees) are to implement the affirmative action plan incorporated into the company's official HR policy. Following this plan, some activities aimed at identification of gender imbalanced areas of the current work force, the establishment of reasonable aims, as well as deadlines for increasing female employment opportunities are to be addressed in order to increase the participation of women in the workplace. With the traditional approach to a woman known as "homemaker, mother, wife, assistant", it is impossible to achieve great results in fostering equality among men and women in mining in the Arctic.

\section{Results}

As part of the analysis of the demographic factor impact on GRP, the authors grouped these indicators by administrative-territorial entities of the Russian Arctic from 2010 to 2019. The results are shown in Table 6.

Based on the results of the grouping, it can be seen that in all regions under analysis there is an increase in GRP along with a simultaneous decrease in the population, including the female one. The exception being the Yamalo-Nenets Autonomous Okrug and also the Republic of Sakha (Yakutia) where statistics show an upward trend. Of interest is the female predominance over the male population (with the exception of the Chukotka Autonomous Okrug) in most of the regions analysed. The Yamal-Nenets Autonomous Okrug achieved a relatively stable gender parity.

Table 6. Interdependency of the demographic factor on the economic indicators of the region [45-47].

\begin{tabular}{cccccccccccc}
\hline Indicator $\backslash$ Year & $\mathbf{2 0 1 0}$ & $\mathbf{2 0 1 1}$ & $\mathbf{2 0 1 2}$ & $\mathbf{2 0 1 3}$ & $\mathbf{2 0 1 4}$ & $\mathbf{2 0 1 5}$ & $\mathbf{2 0 1 6}$ & $\mathbf{2 0 1 7}$ & $\mathbf{2 0 1 8}$ & $\mathbf{2 0 1 9}$ \\
\hline \multicolumn{7}{c}{ Arkhangelsk region, including the Nenets Autonomous Okrug } \\
\hline GRP, mln rub & 372.8 & 439.1 & 472.4 & 500.0 & 542.7 & 627.7 & 713.0 & 759.2 & 865.7 & 890.1 \\
\hline $\begin{array}{c}\text { Population, people, } \\
\text { including } \\
\text { men }\end{array}$ & $1,237,493$ & $1,224,880$ & $1,213,533$ & $1,202,295$ & $1,191,785$ & $1,183,323$ & $1,174,078$ & $1,165,750$ & $1,155,028$ & $1,144,119$ \\
women & 577,321 & 571,811 & 566,990 & 562,263 & 557,554 & 553,906 & 549,905 & 546,244 & 541,212 & 536,282 \\
60,172 & 653,069 & 646,543 & 640,032 & 634,231 & 629,417 & 624,173 & 619,506 & 613,816 & 607,837 \\
\hline
\end{tabular}


Table 6. Cont.

\begin{tabular}{|c|c|c|c|c|c|c|c|c|c|c|}
\hline Indicator $\backslash$ Year & 2010 & 2011 & 2012 & 2013 & 2014 & 2015 & 2016 & 2017 & 2018 & 2019 \\
\hline \multicolumn{11}{|c|}{ The Republic of Karelia } \\
\hline GRP, bln rub & 120.5 & 155.0 & 160.8 & 178.6 & 191.2 & 212.0 & 231.4 & 251.8 & 280.0 & 325.1 \\
\hline $\begin{array}{l}\text { Population, people, } \\
\text { including } \\
\text { men } \\
\text { women }\end{array}$ & $\begin{array}{l}648,718 \\
295,801 \\
352,917\end{array}$ & $\begin{array}{l}642,582 \\
292,847 \\
349,735\end{array}$ & $\begin{array}{l}639,681 \\
291,485 \\
348,196\end{array}$ & $\begin{array}{l}636,932 \\
290,190 \\
346,742\end{array}$ & $\begin{array}{l}634,402 \\
289,203 \\
345,199\end{array}$ & $\begin{array}{l}632,533 \\
288,451 \\
344,082\end{array}$ & $\begin{array}{l}629,875 \\
287,160 \\
342,715\end{array}$ & $\begin{array}{l}627,083 \\
285,895 \\
341,188\end{array}$ & $\begin{array}{l}622,484 \\
283,925 \\
338,559\end{array}$ & $\begin{array}{l}618,056 \\
281,876 \\
336,180\end{array}$ \\
\hline \multicolumn{11}{|c|}{ The Komi Republic } \\
\hline GRP, bln rub & 353.8 & 435.9 & 479.1 & 482.3 & 484.2 & 528.4 & 547.6 & 575.6 & 665.7 & 720.6 \\
\hline $\begin{array}{l}\text { Population, people, } \\
\text { including } \\
\text { men } \\
\text { women }\end{array}$ & $\begin{array}{l}911,977 \\
430,947 \\
481,030\end{array}$ & $\begin{array}{l}899,215 \\
424,628 \\
474,587\end{array}$ & $\begin{array}{l}889,837 \\
420,307 \\
469,530\end{array}$ & $\begin{array}{l}880,639 \\
415,923 \\
464,716\end{array}$ & $\begin{array}{l}872,057 \\
412,109 \\
459,948\end{array}$ & $\begin{array}{l}864,424 \\
408,382 \\
456,042\end{array}$ & $\begin{array}{l}856,831 \\
404,376 \\
452,455\end{array}$ & $\begin{array}{l}850,554 \\
401,548 \\
449,006\end{array}$ & $\begin{array}{l}840,873 \\
396,731 \\
444,142\end{array}$ & $\begin{array}{l}830,235 \\
391,758 \\
438,477\end{array}$ \\
\hline \multicolumn{11}{|c|}{ Murmansk region } \\
\hline GRP, bln rub & 233.4 & 263.8 & 283.8 & 306.6 & 328.3 & 401.6 & 432.4 & 442.6 & 521.0 & 616.9 \\
\hline $\begin{array}{l}\text { Population, people, } \\
\text { including } \\
\text { men } \\
\text { women }\end{array}$ & $\begin{array}{l}799,765 \\
379,697 \\
420,068\end{array}$ & $\begin{array}{l}794,077 \\
378,915 \\
415,162\end{array}$ & $\begin{array}{l}787,948 \\
376,408 \\
411,540\end{array}$ & $\begin{array}{l}780,401 \\
373,287 \\
407,114\end{array}$ & $\begin{array}{l}771,058 \\
369,178 \\
401,880\end{array}$ & $\begin{array}{l}766,281 \\
366,899 \\
399,382\end{array}$ & $\begin{array}{l}762,173 \\
365,019 \\
397,154\end{array}$ & $\begin{array}{l}757,621 \\
363,208 \\
394,413\end{array}$ & $\begin{array}{l}753,557 \\
362,058 \\
391,499\end{array}$ & $\begin{array}{c}748,056 \\
359,6263 \\
88,430\end{array}$ \\
\hline \multicolumn{11}{|c|}{ The Yamalo-Nenets Autonomous Okrug } \\
\hline GRP, bln rub & 782.2 & 966.1 & 1191.3 & 1375.9 & 1633.4 & 1791.8 & 2025.5 & 2453.6 & 3083.5 & 3125.2 \\
\hline $\begin{array}{l}\text { Population, people, } \\
\text { including } \\
\text { men } \\
\text { women }\end{array}$ & $\begin{array}{l}524,141 \\
259,974 \\
264,167\end{array}$ & $\begin{array}{l}524,925 \\
275,428 \\
249,497\end{array}$ & $\begin{array}{l}536,558 \\
262,699 \\
273,859\end{array}$ & $\begin{array}{l}541,612 \\
264,685 \\
276,927\end{array}$ & $\begin{array}{l}539,671 \\
263,847 \\
275,824\end{array}$ & $\begin{array}{l}539,985 \\
273,125 \\
266,860\end{array}$ & $\begin{array}{l}534,104 \\
266,305 \\
267,799\end{array}$ & $\begin{array}{l}536,049 \\
262,289 \\
273,760\end{array}$ & $\begin{array}{l}538,547 \\
269,111 \\
269,436\end{array}$ & $\begin{array}{l}541,479 \\
271,551 \\
269,928\end{array}$ \\
\hline \multicolumn{11}{|c|}{ Krasnoyarsk Territory } \\
\hline GRP, bln rub & 1684.3 & 1760.8 & 1666.2 & 1688.9 & 1731.1 & 1849.6 & 1849.9 & 1980.9 & 2280 & 2692.2 \\
\hline $\begin{array}{l}\text { Population, people, } \\
\text { including } \\
\text { men } \\
\text { women }\end{array}$ & $\begin{array}{c}2,832,85 \\
41,218,12 \\
71,614,727\end{array}$ & $\begin{array}{l}2,829,105 \\
1,216,515 \\
1,612,590\end{array}$ & $\begin{array}{l}2,838,396 \\
1,220,510 \\
1,617,886\end{array}$ & $\begin{array}{l}2,846,475 \\
1,223,984 \\
1,622,491\end{array}$ & $\begin{array}{l}2,852,810 \\
1,226,708 \\
1,626,102\end{array}$ & $\begin{array}{l}2,858,773 \\
1,286,447 \\
1,572,326\end{array}$ & $\begin{array}{l}2,866,490 \\
1,289,920 \\
1,576,570\end{array}$ & $\begin{array}{l}2,875,301 \\
1,293,885 \\
1,581,416\end{array}$ & $\begin{array}{l}2,876,497 \\
1,343,804 \\
1,532,693\end{array}$ & $\begin{array}{l}2,874,026 \\
1,342,557 \\
1,531,469\end{array}$ \\
\hline \multicolumn{11}{|c|}{ The Republic of Sakha (Yakutia) } \\
\hline GRP, bln rub & 640.6 & 753.4 & 794.8 & 790.0 & 826.5 & 849.7 & 925.0 & 941.4 & 1084.6 & 1220.3 \\
\hline $\begin{array}{l}\text { Population, people, } \\
\text { including } \\
\text { men } \\
\text { women }\end{array}$ & $\begin{array}{l}958.5 \\
465.9 \\
492.6\end{array}$ & $\begin{array}{l}958.3 \\
465.7 \\
492.6\end{array}$ & $\begin{array}{l}955.9 \\
464.6 \\
491.3\end{array}$ & $\begin{array}{l}955.6 \\
464.1 \\
491.4\end{array}$ & $\begin{array}{l}954.8 \\
463.5 \\
491.3\end{array}$ & $\begin{array}{l}956.9 \\
464.6 \\
492.3\end{array}$ & $\begin{array}{l}959.7 \\
465.7 \\
494.0\end{array}$ & $\begin{array}{l}962.8 \\
467.1 \\
495.7\end{array}$ & $\begin{array}{l}964.3 \\
467.9 \\
496.4\end{array}$ & $\begin{array}{l}967.0 \\
469.4 \\
497.6\end{array}$ \\
\hline \multicolumn{11}{|c|}{ The Chukotka Autonomous Okrug } \\
\hline GRP, bln rub & 60.4 & 65.9 & 63.3 & 58.7 & 73.3 & 70.5 & 73 & 71.6 & 78.1 & 94.8 \\
\hline $\begin{array}{l}\text { Population, people, } \\
\text { including } \\
\text { men } \\
\text { women }\end{array}$ & $\begin{array}{l}51,179 \\
25,719 \\
25,460\end{array}$ & $\begin{array}{l}50,346 \\
25,236 \\
25,110\end{array}$ & $\begin{array}{l}50,988 \\
25,868 \\
25,120\end{array}$ & $\begin{array}{l}50,780 \\
25,832 \\
24,948\end{array}$ & $\begin{array}{l}50,555 \\
25,737 \\
24,818\end{array}$ & $\begin{array}{l}50,540 \\
25,769 \\
24,771\end{array}$ & $\begin{array}{l}50,157 \\
25,522 \\
24,635\end{array}$ & $\begin{array}{l}49,822 \\
25,387 \\
24,435\end{array}$ & $\begin{array}{l}49,348 \\
25,090 \\
24,258\end{array}$ & $\begin{array}{l}49,963 \\
25,213 \\
24,450\end{array}$ \\
\hline
\end{tabular}

The growth in the male population of the Krasnoyarsk Territory is mainly associated with an increase of production of both oil (related to the discovery of the new field by the subsidiary of Rosneft-RN-Vankor; the oil company continues to implement an integrated exploration programme aimed at increasing the resource base of the Vostok Oil project and complex ores (the activities of Russia's largest non-ferrous metallurgy company PJSC Norilsk Nickel $[48,49])$ in the North-East region of Russia, as well as with the fact that part of the southern part of the Krasnoyarsk Territory is not included in the Russian Arctic.

In the 9 year period, GRP is growing due to inflation and market conditions for certain types of raw materials, while the population is declining, economic conditions in these regions continue to deteriorate, social crises are exacerbated, and living standards are plummeting ever faster in the continued absence of migration to the Russian Arctic regions. 
That is, the GRP data increase is mainly caused by inflation, since this growth over 10 years is not so significant compared with the rising of stock-market prices for the most types of mineral resources except for the regions where mining is growing rapidly. Such regions include the Yamal-Nenets Autonomous Okrug, actively developing oil and gas production, partially using advanced processing (e.g., the construction of the YAMAL LNG plant $[50,51])$. In this regard, the increase in the population, including the female one, can be expected in this area by engaging highly qualified specialists.

The population is expected to decline in the rest of the Russian Arctic regions serving as an immediate and accurate indication of assessing the economic condition of the region as a whole. The outflow of the population indicates a deterioration in economic and social conditions. Certain regions with GRP data going to increase in the coming decades are regions having raw materials being widely demanded on the world markets such as oil, gas, polymetals, and diamonds.

A case in point is strategic miscalculations and errors in the development of the Svalbard archipelago. Despite Spitsbergen's vast regions opened to large-scale industrial exploitation, Russian business barely exists there. At the same time, state property being used extremely inefficiently requires costs both to maintain and to guarantee the continuity of the jurisdiction, i.e., Norwegian law establishes the maximum period of object abandonment. In that regard, the proposals amounted to the development of the Russian part of the archipelago in one form or another are reduced to the need of permanent growth of financing. Furthermore the scope of the feasible work plan has not been estimated. Having no alternative, development strategies to mining Russia still relies heavily on coal mining in the archipelago [52].

Science and tourism experienced an increase at the turn of both the 20th and the 21st centuries. Internationalisation is said to be one of the positive trends in the history of Spitsbergen. Over the past decade, the Arctic potential has been strengthened due to the tourism development, scientific and technological advances, as well as education growth. Russia is to take advantage of seizing opportunities for international collaboration as well as change the outdated economic activities in the region.

The research focuses on the analysis of the gender composition of the population in the Arctic. The Arctic area is large with low population density. To implement a gender mainstreaming approach, gender indicators were employed serving as important tools that allow integrating gender in all statistical data obtained. The gender analysis in the Arctic regions of the first and second territorial categories shows that there are more women than men in the overwhelming majority (Table 7). In Chukotka only, there are fewer women than men (=963).

Table 7. Indicators of gender balance in the Russian Arctic (2019) [53].

\begin{tabular}{ccc}
\hline \multicolumn{2}{c}{ Geographic Areas } & Gender Indicator \\
\hline $\begin{array}{c}\text { First territorial category-regions } \\
\text { completely assigned to the zone of } \\
\text { the North }\end{array}$ & Murmansk region & 1086 \\
& $\begin{array}{c}\text { The Nenets Autonomous Area } \\
\text { The Yamalo-Nenets Autonomous Okrug } \\
\text { The Chukotka Autonomous Okrug }\end{array}$ & 1051 \\
& Arkhangelsk Region (7 urban and & 963 \\
Second territorial category-regions & municipal districts) & 1134 \\
partially assigned to the zone of the & The Republic of Karelia \\
North & The Komi Republic & 1193 \\
& Krasnoyarsk Territory & 1118 \\
& Republic of Sakha (Yakutia) & 1141 \\
\hline
\end{tabular}

Since the beginning of the century, the gender ratio has changed slightly; in 2010 it amounted to 1.163 in the Russian Federation as a whole. There were 1156 women per 1000 men in 2019. In the Arctic, the indicator of gender balance is lower than the average one for Russia in all regions except for the Republic of Karelia. In no region does the indicator reach the average for the Russian Federation. In total, at the beginning of 2020, 68.1 million men and 78.6 million women lived in Russia. 
Until recently, female mine workers seemed to be rare instances in the Arctic region. Women used to have internal barriers that hampered professional progress. In the public domain, there are few cases of successful careers of women in the mining industry in the Arctic region that are still impressive and inspiring. On the website of Women in Mining Russia one can find such stories. For example, being a leading geotechnical engineer of Polymetal International plc, A. Bogoslovskaya is engaged in development of efficient mining methods as well as assessment of environmental and occupational safety in mining industry. As a rule, women in mining have had to overcome stereotypes not only on the part of society, but also within their own family. However, positive examples show that women are able to succeed in the mining industry of the Arctic region. Thus, such experience can popularise both engineering education in general and mining, in particular, and make the Arctic region more attractive for professional development not only of men, but also of women. Based on the analysis of the statistics, it can be assumed that mining is still lagging behind in its progress on gender equality (Table 8 ).

Table 8. Women employed in mining [54-56].

\begin{tabular}{cc}
\hline Country & $\begin{array}{c}\text { Proportion of Women Employed } \\
\text { in Mining, \%, 2019 }\end{array}$ \\
\hline Russia & 44.7 \\
Finland & 15.9 \\
Sweden & 5.9 \\
Norway & 25.1 \\
Iceland & 5.1 \\
Denmark & 36.9 \\
Canada & 53 \\
The USA & 15.3 \\
\hline
\end{tabular}

The proportion of women employed by mining companies varied significantly from $5 \%$ in Iceland to around 50\% both in Russia and Canada.

\section{Discussion}

As the Arctic becomes more accessible due to melting of sea ice, use of the Arctic zone as a strategic resource has gained international attention resulting in increased economic and social activities in the region. The majority of scientists agree that there is no single international treaty defining the boundaries of the territories included in the Arctic region $[57,58]$. The Arctic boundaries remain the subject of many-sided studies and discussions.

Analysing the demographic characteristics of the northern territories, a great number of researchers agree that the features of population settlement in the Arctic are predetermined by its formidable climate with year-round severe frosts, long polar nights, swampy tundra determining the seasonality of activities in most regions, lack of infrastructure, as well as long-distance communications.

Priorities of the development of the certain sectors of the economy are certain to create the demand for occupations in the Arctic zone of Russia. State-of-the-art technologies and digitalisation of production result in blurring the boundaries between male and female professions in the mining industry. The Russian Digital Economy Programme is expected to affect positively all spheres of society, including increasing female business competitiveness, reducing production costs, creating new jobs, improving the quality and standard of living of women. Academically qualified female specialists can work in safe working environment and be definitely employed in the Arctic.

The contribution of this study to the development of the Arctic region is in the comprehensive approach to the complex demographic analysis of the Arctic regions of Russia. The article presents the prospect of further research into the issue of women's involvement in industry of the Arctic, since families in which both men and women are 
employed in production will contribute to the growth and stabilisation of the number of people living in the Arctic territories.

The basis for the success of population growth lies, first of all, in the presence of opportunities of various kinds-harmonious development of the personality, cultural ties, living conditions, possibility of communication not only in the production sphere, but also in the field of leisure. The consequence of this is the need for creation and development of infrastructure facilities, the lack of which is noted in the regions of the Far North at the present time. Therefore, it is advisable to consider not only the purely economic indicators of the region, but also socially oriented projects that contribute to the development of such areas with hostile climate.

Arctic regulations on women's involvement in mining and their implementation addressing gender challenges should be female performance-based, emphasising prevention of loss of women mine workers, and use of the effective technologies to improve their industrial safety and economic viability. Conflicting regulatory requirements on women's participation in mining should be harmonised. Unawareness of gender-specific roles in the Arctic paves the way for both inadequate treatment of female mining specialists and neglecting their talents.

\section{Conclusions}

By way of conclusion, we may state that the regional indicator of GRP at fairly high values does not always characterise the long-term perspective of the region. This is due to the fact that the exploitation of deposits of raw materials of high cost has a limited period of time. The economic situation may be drastically altered by the decrease in production or changes in the commodity market. Long-term programmes of the Arctic development require an understanding of the strategic positioning of such regions on a scale for the next century. The current need to develop the Arctic territories will lead to their natural economic growth. However, this goal cannot be achieved without steady population growth which in its turn largely depends on GRP per capita. Certain steps are being taken, such as infrastructure construction for the Northern Sea Route and mining exploration activities in order to create jobs and boost the economy. Without strengthening the indigenous population in the regions of the Russian Arctic, the implementation of such projects is very difficult and costly.

Investment in the mining industry must be followed by the investment in regional infrastructure (urban improvement, the development of related industries, the attraction of knowledge-intensive and high-tech industries, scientific centres and clusters). To meet future claims, investing is to be based on long-term strategic programmes that cannot be done without women's participation.

At present, women's involvement in the labour market continues to be restricted at some industries related to hazardous and harmful factors in the occupational environment or constant physical activities such as chemical production (production of mercury, chlorine, fluorine, phosphorus, etc.), in mining, as well as in the field of metalworking, oil and gas production, ferrous and non-ferrous metallurgy. According to the list of factors dangerous to women's reproductive health, affecting the health of the future generation and having distant consequences, women are prohibited from working in a number of capacities, from certain types of work and positions including drilling and blasting operations, working on heavy mining machines and mechanisms (e.g., drilling machines, vibration equipment), etc. Some construction machines, viz. bulldozers, excavators, auto graders, will remain inaccessible to women.

At the same time, women can occupy positions of managers, scientific or technical specialists who are not involved in heavy physical work. Mainly, in the field of mining and exploration, women are senior competent specialists: geologists, engineers, laboratory assistants, technologists, ore enrichment specialists, mining surveyors, etc. 
In the short term, there may be a deviation from the shift method of work as well as the reduction of work duration, changes in logistical factors because of the assimilation of the employees near the working place.

It can therefore be concluded that percentage of indigenous inhabitants contributing to the economic development of the leading industries has to be increased for the substantial progress of the entire Arctic region. A related issue has to do with the infrastructure design, women's employment in economic sectors being inextricably linked, and above all, the need for an information platform from where to assess the sustainability of the Arctic communities in terms of natural wealth management and vulnerability towards global policies and trends for the period of several decades.

All demographic characteristics of the Arctic are extremely heterogeneous both between countries and the territories of individual countries. The study concluded that the Russian Federation has significantly undiscovered female potential in the Arctic, similar to the foreign Arctic regions. In the foreign Arctic, women are currently allowed to work underground, and women miners are protected from discrimination by law.

In the overwhelming majority of the Russian Arctic regions, women predominate, but there are fewer of them per 1000 men than the average data for the Russian Federation. Despite proven operational capability and technological advances, pursuing a career in mining in the Russian Arctic region by women is hindered by the legal regulatory framework and a lack of public confidence that it could be conducted safely and responsibly. Women as a highly skilled engineering workforce are underrepresented in mining in the Arctic. Although, labour market trends can be transformed under the influence of modern technological advances such as digitalisation for the foreseeable future.

The development of the Arctic regions, in our opinion, should be based on long-term promising macro-projects, the implementation of which is impossible without participation of foreign investment stakeholders. For example, development of a project for the Northern Sea Route, which allows to establish logistic links between Europe and the Far East regions, tourist routes, scientific and environmental programs, etc.

As a result of the study, a correlation between the most important parameter characterising the region's economy-GRP-and demographic indicators in dynamics over several years was revealed. The development of the above projects can certainly change the current state both in terms of the economy and in terms of demography (population growth) in the foreseeable future.

Author Contributions: Conceptualisation, I.G.G., I.S.O.; methodology, E.I.G.; investigation, I.S.O., E.I.G.; resources, I.S.O., E.I.G.; data curation, E.I.G., I.G.G.; writing-original draft preparation, I.S.O., E.I.G.; writing-I.G.G.; visualisation, E.I.G.; supervision, I.G.G.; project administration, I.G.G. All authors have read and agreed to the published version of the manuscript.

Funding: The research was performed at the expense of the subsidy for the state assignment in the field of scientific activity for 2021 No. FSRW-2020-0014.

Institutional Review Board Statement: The study was conducted according to the guidelines of the Declaration of Helsinki, and approved by the Institutional Review Board of the Saint Petersburg Mining University (protocol code № 1 approved on 30 August 2021).

Informed Consent Statement: Informed consent was obtained from all subjects involved in the study.

Data Availability Statement: Data supporting reported results can be found: https:/ /arhangelskstat. gks.ru/ (accessed on 10 November 2021); https://krl.gks.ru/ (accessed on 11 May 2021); https: // komi.gks.ru/grp (accessed on 11 May 2021); http:/ / komi.old.gks.ru/wps/wcm/connect/rosstat ts/komi/ru/statistics/population/ (accessed on 11 May 2021); https:/ / murmanskstat.gks.ru/folder/ 72764?print=1 (accessed on 11 May 2021); http: / / murmanskstat.old.gks.ru/wps/wcm/connect/ rosstat_ts / murmanskstat/ru/statistics/population/ (accessed on 11 May 2021); https:/ / tumstat. gks.ru/ofstat_ynao (accessed on 11 May 2021); https:/ / krasstat.gks.ru/folder/32970 (accessed on 11 May 2021); https:/ / krasstat.gks.ru/folder/93515 (accessed on 11 May 2021). 
Conflicts of Interest: The authors declare no conflict of interest. The funders had no role in the design of the study; in the collection, analyses, or interpretation of data; in the writing of the manuscript, or in the decision to publish the results.

\section{References}

1. Prskawetz, A.; Fent, T.; Barthel, W. The Relationship Between Demographic Change and Economic Growth in the EU. Rep. Tender VT. 2005, 35, 111-112.

2. Mester, L.J. Demographics and Their Implications for the Economy and Policy. In Proceedings of the Cato Institute's 35th Annual Monetary Conference: The Future of Monetary Policy, Washington, DC, USA, 16 November 2017.

3. Smits, C.C.A.; Justinussen, J.C.S.; Bertelsend, R.G. Human capital development and a Social License to Operate: Examples from Arctic energy development in the Faroe Islands, Iceland and Greenland. Energy Res. Soc. Sci. 2016, 16, 122-131. [CrossRef]

4. Chanysheva, A.; Kopp, P.; Romasheva, N.; Nikulina, A. Migration Attractiveness as a Factor in the Development of the Russian Arctic Mineral Resource Potential. Resources 2021, 10, 65. [CrossRef]

5. Lazhentsev, V.N. Comprehensive studies of territorial development. Regionalism 2015, 2, 42-48.

6. Litvinenko, V.S.; Tsvetkov, P.S.; Molodtsov, K.V. The social and market mechanism of sustainable development of public companies in the mineral resource sector. Euras. Ming 2020, 1, 36-41. [CrossRef]

7. Bloom, L. Gender on Ice: American Ideologies of Polar Expeditions; University of Minnesota Press: Minneapolis, MN, USA, 1993.

8. Glasberg, E. Antarctica as Cultural Critique: The Gendered Politics of Scientific Exploration and Climate Change; Palgrave Macmillan: New York, NY, USA, 2012.

9. Chipman, E. Women on the Ice: A History of Women in the Far South; Melbourne University: Melbourne, Australia, 1986.

10. Carey, M.; Jackson, M.; Antonello, A.; Rushing, J. Glaciers, gender, and science: A feminist glaciology framework for global environmental change research. Prog. Human Geogr. 2016, 40, 770-793. [CrossRef]

11. Seag, M. Women need not apply: Gendered institutional change. Polar J. 2017, 7, 319-335. [CrossRef]

12. Rosner, V. Gender and Polar Studies: Mapping the Terrain. Signs J. Women Cult. Soc. 2009, 34, 489-494. [CrossRef]

13. Lahiri-Dutt, $\mathrm{K}$. The act that shaped the gender of industrial mining: Unintended impacts of the British mines act of 1842 on women's status in the industry. Extr. Ind. Soc. 2019, 7, 389-397. [CrossRef]

14. Marsh, H.W.; Jayasinghe, U.W.; Bond, N.W. Gender differences in peer reviews of grant applications: A substantivemethodological synergy in support of the hypothesis model. J. Inform. 2011, 5, 167-180. [CrossRef]

15. Bell, R.E.; Koenig, L.S. Harassment in science is real. Science 2017, 358, 12-23. [CrossRef]

16. Starkweather, S.; Derry, K.; Crain, R. Leveling the Field-Tips for Inclusive Arctic Field Work. International Arctic Science Committee. Available online: https://iasc.info/outreach/news-archive/418-leveling-the-fieldtips-for-inclusive-arctic-fieldwork (accessed on 1 September 2021).

17. Association of Polar Early Career Scientists [APECS]. Polar Policy: How Polar Agencies are Changing Their Policies to Be More Inclusive. Webinar on the 6th February 2019. Available online: https://vimeo.com/319967816?fbclid=IwAR2DPnfbO8KtffezhlL5 0B4crs6pfxIl712xSzQt8JE08L8AV826FRsC9A (accessed on 1 September 2021).

18. Smieszek, G.; Prior, T.; Turning Our Eyes to Women and Gender in the Arctic. Arctic Relations. Available online: https: //www.arctic-relations.info/in-the-field (accessed on 1 September 2021).

19. Women of the Arctic: Bridging Policy, Research \& Lived Experience. Available online: https://arcticyearbook.com/arcticyearbook/2018/2018-briefing-notes/297-women-of-the-arctic-bridging-policy-research-lived-experience (accessed on 1 September 2021).

20. Litvinenko, V.S. Arctic Potential: Realizing the Promise of US Arctic Oil and Gas Resources. Committee on Arctic Research Rex W. Tillerson, Chair. National Petroleum Council. Available online: https://www.npcarcticreport.org/pdf/ARExecutive_SummaryFinal.pdf (accessed on 10 May 2021).

21. Industrial Companies for Gender Balance. Available online: https:/ / www.forbes.ru/forbes-woman/394857-promyshlennost-zagendernyy-balans-polymetal-nornikel-i-deloitte-zapustili (accessed on 11 May 2021).

22. Supplemental Assessment to the 2015 Arctic Potential Realizing the Promise of U.S. Arctic Oil and Gas Resources. Available online: https: / / www.npcarcticreport.org/pdf/2019-Arctic_SA-LoRes.pdf (accessed on 1 September 2021).

23. Gjørv, G.H. Finding Gender in the Arctic: A Call to Intersectionality and Diverse Methods. In: The Interconnected Arctic-Arctic Congress. Available online: https://www.researchgate.net/publication/318153545_Finding_Gender_in_the_Arctic_A_Call_ to_Intersectionality_and_Diverse_Methods (accessed on 20 April 2021).

24. Introduction: Feminist Approaches and the Study of Gender in Arctic Social Sciences. Available online: https://www.researchgate. net/publication/327222568_Introduction_feminist_approaches_and_the_study_of_gender_in_Arctic_social_sciences (accessed on 1 September 2021).

25. Seag, M.; Badhe, R.; Choudhry, I. Intersectionality and International Polar Research. Available online: https:/ / www.cambridge org/core/journals / polar-record/article/intersectionality-andinternational-polarresearch/4F9424A0A634F12565ED9AB903C4 336F (accessed on 26 April 2021).

26. Fauzer, V.V.; Smirnov, A.V. The World's Arctic: Natural Resources, Population Distribution, Economics. J. Arctic $2018,3,6-22$.

27. Michaud, D. After the Ice: Mineral Riches of the Arctic. Available online: https://www.911metallurgist.com/blog/mineralrichesof-the-arctic (accessed on 1 September 2021). 
28. International Arctic Science Committee. Soliciting Nominations for the 2019 IASC Medal. Available online: https:/ /iasc.info/ outreach/news-archive/460-soliciting-nominations-for-the-2019-iasc-medal (accessed on 1 September 2021).

29. Kondratiev, V.B. Mineral resources and future of the Arctic. Min. Ind. J. 2020, 1, 87-96. [CrossRef]

30. Bird, K.J.; Charpentier, R.R.; Gautier, D.L.; Houseknecht, D.W.; Klett, T.R.; Pitman, J.K.; Moore, T.E.; Schenk, C.J.; Tennyson, M.E.; Wandrey, C.J. Circum-Arctic Resource Appraisal: Estimates of Undiscovered Oil and Gas North of the Arctic Circle. Available online: https:/ / pubs.usgs.gov/fs/2008/3049/fs2008-3049.pdf (accessed on 1 September 2021).

31. Shaft Man. Career Guidance Program. Available online: http://proforientir42.ru/dt_profession/prohodchik/ (accessed on 11 May 2021).

32. Hiring. US Department of Labor. Available online: https://www.dol.gov/general/topic/hiring/affirmativeact (accessed on 26 April 2021).

33. Kazanin, O.I.; Drebenstedt, C. Mining Education in the 21st Century: Global Challenges and Prospects. J. Min. Inst. 2017, 225, 369-375.

34. Rassadina, S. Cultural foundations of the concept of edutainment as a strategy for the formation of common cultural competence in universities of a non-humanitarian profile. J. Min. Inst. 2016, 219, 498-503.

35. Katuntsov, E.V.; Kultan, J.; Makhovikov, A.B. Application of Electronic Learning Tools for Training of Specialists in the Field of Information Technologies for Enterprises of Mineral Resources Sector. J. Min. Inst. 2017, 226, 503-508.

36. Comprehensive_Research_Arctic Areas of Cooperation of Saint-Petersburg and the Russian Arctic. Available online: https: / / habstat.gks.ru/folder/66945 (accessed on 1 September 2021).

37. Federov, V.P.; Zhuravel, V.P.; Grinyaev, S.N.; Medvedev, D. Scientific Approaches to Defining the Territorial Boundaries of the Arctic. Available online: https://www.researchgate.net/publication/335002478_Scientific_approaches_to_defining_the_ territorial_boundaries_of_the_Arctic (accessed on 30 May 2021).

38. Golovina, E.I.; Pashkevich, N.V. Current issues in the system of state management of underground water development in the territory of the Russian Federation. J. Min. Inst. 2014, 210, 99-107.

39. Tolvanen, A.; Eilu, P.; Juutinen, A.; Kangas, K.; Kivinen, M.; Markovaara-Koivisto, M.; Naskali, A.; Salokannel, V.; Tuulentie, S.; Similä, J. Mining in the Arctic environment-A review from ecological, socioeconomic and legal perspectives. J. Environ. Man. 2019, 233, 832-844. [CrossRef]

40. Interdisciplinary Arctic Research. Areas of cooperation of Saint-Petersburg and the Arctic regions of the Russian Federation. 2020. Available online: https:/ / russiancouncil.ru/en/projects/regional/arctic/ (accessed on 1 September 2021).

41. Kuletskiy, K.V.; Zhunda, S.V.; Rudakov, M.L.; Pasynkov, A.V.; Sobyanin, D.S. Using an occupational risk management procedure in order to improve labor protection training for workers in open pit mining organizations. Ind. Saf. 2020, 2, 74-79.

42. Kazanin, O.I.; Rudakov, M.L.; Kolvakh, K.A. Occupational safety and health in the sector of coal mining. Int. J. Civ. Eng. Tech. 2018, 6, 1333-1339.

43. Gendler, S.G.; Rudakov, M.L.; Falova, E.S. Analysis of the risk structure of injuries and occupational diseases in the mining industry of the Far North of the Russian Federation. Nauk. Visnyk Nat. Hirn. Univ. 2020, 3, 81-85. [CrossRef]

44. Executive Order. USA. Available online: https://www.eeoc.gov/laws/statutes/index.cfm (accessed on 1 September 2021).

45. Territorial Authority. The Republic of Karelia. Available online: https://krl.gks.ru/ (accessed on 21 September 2021).

46. Territorial Authority. Yamalo-Nenets Autonomous Okrug. Available online: https://tumstat.gks.ru/ofstat_ynao (accessed on 21 September 2021).

47. Territorial Authority. Krasnoyarsk Territory. Available online: https://glavportal.com/materials/na-granice-krasnoyarskogokraya-i-yanao-rosneft-otkryla-novoe-neftegazovoe-mestorozhdenie (accessed on 21 September 2021).

48. Norilsk Nickel. Available online: https:/ / www.nornickel.ru/ (accessed on 21 September 2021).

49. Savard, C.; Nikulina, A.Y.; Mecemenne, C.; Mokhova, E.A. The Electrification of Ships Using the Northern Sea Route: An Approach. J. Open Inn. Tech. Mark. Compl. 2020, 6, 13-15. [CrossRef]

50. Belova, M.; Popov, A.; Iakovleva, E.V. Mining and Environmental Monitoring at Open-Pit Mineral Deposits. J. Ecol. Eng. 2019, 5 , 172-178.

51. YAMAL LNG. Available online: http:/ / yamallng.ru/ (accessed on 21 September 2021).

52. Dvoynikov, M.V.; Nutskova, M.V.; Blinov, P.A. Developments made in the field of drilling fluids by Saint Petersburg mining University Developments made in the field of drilling fluids by Saint Petersburg mining University. Int. J. Eng. Trans. 2020, 4, 702-711.

53. Glotko, O.L. Women and Men of Russia; Rosstat: Moscow, Russia, 2018; pp. 97-98.

54. She Figures 2018. European Union. 2019. Available online: https://blogs.uni-bremen.de/starbiosbremenenglish/files/2019/09/ SHE_figures_2018.pdf (accessed on 1 September 2021).

55. Women in STEM 2019. Available online: https://www.stemwomen.co.uk/blog/2019/09/women-in-stem-percentages-ofwomen-in-stem-statistics (accessed on 21 September 2021).

56. MINT. Zahlen, Daten, Fakten. Arbeitsmarkt und Karrierechancen in Mathematik, Informatik, Naturwissenschaften und Technik. 2020. Available online: https:/ / cdn2.vol.at/2013/02/MINT2020_zahlen.pdf (accessed on 1 September 2021).

57. Kirsanova, N.Y.; Lenkovets, O.M.; Nikulina, A.Y. The Role and Future Outlook for Renewable Energy in the Arctic Zone of Russian Federation European. Resh. Stud. J. 2018, 2, 356-368.

58. Powell, K. These labs are remarkably diverse-Here's why they're winning at science. Nature 2018, 558, 19-22. [CrossRef] 